\title{
YIELD OF THREE NEWLY DEVELOPED MUSTARD VARIETIES AS AFFECTED BY IRRIGATION AT DIFFERENT GROWTH STAGES
}

\section{Monira Khatun ${ }^{1}$, Partha Biswas ${ }^{2}$, Md. Moudud Hasan ${ }^{3^{*}}$, Nazmun Nahar Karim ${ }^{4}$ and MG Mostofa Amin ${ }^{1}$}

1Department of Irrigation and Water Management, Bangladesh Agricultural University, Mymensingh-2202, Bangladesh; ${ }^{2}$ International Maize and Wheat Improvement Center, Faridpur Hub, Faridpur; ${ }^{3}$ Department of Agricultural and Industrial Engineering, Hajee Mohammad Danesh Science and Technology University, Dinajpur-5200; ${ }^{4}$ Bangladesh Agricultural Research Council, Farmgate, Dhaka, Bangladesh

*Corresponding author: Md. Moudud Hasan, E-mail: hasan_moudud@yahoo.com

\section{ARTICLE INFO}

\section{Received}

19.07.2015

Accepted

14.08.2015

Online

18.08.2015

Key words

Mustard variety

Irrigation

Growth stage

Oil-seed
Efficient use of water is essential for sustainable crop production and achieving food security especially where water is a scarce resource. A study was conducted at a farmer's field near Rahmatpur, Mymensingh, Bangladesh during November 2012February 2013 to study the effect of irrigation on the yield and yield attributes of three newly developed mustard varieties, namely Binasarisha-7 (Brassica juncea L), Binasarisha-8 (Brassica juncea L), and Binasarisha-4 (Brassica napus L). The experimental soil was silty clay with a bulk density of $1.43 \mathrm{~g} \mathrm{~cm}^{-3}$. There were four irrigation treatments $\left(T_{1}\right.$ : no irrigation; $T_{2}$ : irrigation at vegetative stage; $T_{3}$ : irrigation at flowering stage; $\mathrm{T}_{4}$ : irrigation at vegetative and flowering stage), each replicated three times in a split plot design. Irrigation showed significant effect on the yield attributes of the mustard varieties. The highest yield of $1.43 \mathrm{t} \mathrm{ha}^{-1}$ ( $46 \%$ higher over control) was obtained in treatment $T_{4}$ of variety Binasarisha-7. The lowest yield of $0.63 \mathrm{t} \mathrm{ha}^{-1}$ was obtained in treatment $\mathrm{T}_{1}$ (control) of variety Binasarisha-4. For producing seed yield Binasarisha- 4 was the most responsive to the irrigation treatments $\left(T_{2}-T_{4}\right)$. In contrast, the yield differences among the stage-wise irrigation treatments $\left(T_{2}-T_{4}\right)$ were not statistically significant for Binasarisha-8. The highest water use efficiency of $0.48 \mathrm{t} \mathrm{ha}^{-1} \mathrm{~cm}^{-1}$ was obtained in treatment $T_{1}$ and the lowest of $0.28 \mathrm{t} \mathrm{ha}^{-1} \mathrm{~cm}^{-1}$ was in treatment $T_{4}$. For cultivation of the mustard varieties Binasarisha-4, Binasarisha- 7 and Binasarisha- 8 in this type of climate, irrigation at vegetative and flowering stage may be recommended to produce higher yield.

To cite this article: Khatun M, P Biswas, MM Hasan, NN Karim and MGM Amin, 2015. Yield of three newly developed mustard varieties as affected by irrigation at different growth stages. Res. Agric. Livest. Fish. 2 (2): 197206.

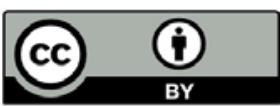

This is an open access article licensed under the terms of the Creative Commons Attribution 4.0 International License

www.agroaid-bd.org/ralf, E-mail: editor.ralf@gmail.com 


\section{INTRODUCTION}

Water is a costly and scarce input for agricultural production system. Judicious use of water in agriculture is therefore essential, especially under limited resource conditions. With increasing global population, the gap between the supply and demand for water is widening and reaching such alarming levels that in some parts of the world it is posing a threat to food security (Hussain et al., 2002; UN Water, 2014). Sufficient access to water is indispensable in raising plants, but scarcity of water is already a critical constraint to farming in many parts of the world (CA, 2007). The global water crisis, particularly in agriculture, has drawn worldwide attention. Water scarcity has already affected more than $40 \%$ of the world population (UN Water, 2014).

More efficient use of water is required for sustainable crop production and achieving food security. Irrigation water has to be utilized in a manner that matches the water needed for crops. Water requirement of crops varies substantially over the growing season mainly due to variation in vegetative cover, soil and climatic condition (Amin et al., 2004; Shekhawat et al., 2012; Singh and Panda, 2012). Estimating crop water requirement based on the soil and climatic condition is an important element for designing and managing irrigation system. Identifying the crop growth stages sensitive to water stress is crucial for the improvement of water use efficiency as well as for maximization of the yield (Mandal et al., 2006; Mila et al., 2013).

Mustard is the major oil seed crop of Bangladesh that covers more than $60 \%$ of the total area cultivated for oil seed (BBS, 2011) and it contributes a major share to the total edible oil production of the country. It is cultivated throughout the semi-arid climate zone of Bangladesh and commonly known as sarisha (Miah and Alam, 2009). At present, about 0.25 Mha of land is put to mustard cultivation in Bangladesh with a total production of mustard oil of $0.24 \mathrm{Mt}_{\text {year }}{ }^{-1}$ (BBS, 2011). Mustard seed contains $40-45 \%$ edible oil and $20-25 \%$ protein (Miah and Alam, 2009). Mustard oilcake is used as high quality manure for crop production and nutritious animal feed, and its demand is rapidly increasing in the expanding animal sector.

The average yield of mustard in Bangladesh is low $\left(0.70 \mathrm{t} \mathrm{ha}^{-1}\right)$ (BBS, 2011) compared to that of other oilseeds growing countries of the world. In addition, the area under mustard cultivation is decreasing because it has to compete with other high value winter crops (Miah and Alam, 2009). Since Bangladesh has been in short of $65-70 \%$ of the demand of the edible oil, a huge amount of foreign currency is being spent every year for importing oil and oil seeds (Miah and Alam, 2009). The shortage of edible oil may be minimized either by increasing area under mustard cultivation or by increasing yield per unit area. Possibility of increasing area under mustard cultivation is meager, but there is scope to increase yield by cultivating high yielding variety under best management practices. The production may also be increased by applying irrigation water at right time (Kahlown et al., 2009) as this crop is grown in dry winter season.

Yield and quality of this crop often suffers due to deficient water supply (Singh and Panda, 2012). In most of the places it cannot produce optimum yield on residual soil moisture only if the rainfall is inadequate (Shekhawat et al., 2012; Bharadwaj et al., 2014). For the successful growth of mustard, irrigation may be required in three critical growth stages (Acharjee, 2013). However, number of irrigation depends on antecedent soil water content in the root zone soil, soil and climatic condition, and varieties (Chauhan and Singh, 2004; Panda et al., 2004; Pandey et al., 2004). To calculate the required irrigation water depth soil water content at different depths of the root zone soil should be measured. In addition, soil-water model like HYDRUS (Šimunek et al., 2013) can also be used cost-effectively to simulate the soil water content in the root zone soil. In this study, HYDRUS model was used to supplement the measured soil water content data. As a part of the oil seed production initiative Bangladesh Institute of Nuclear Agriculture developed Binasarisha-4, Binasarisha-7 and Binasarisha-8. The irrigation demand and yield potential of the new mustard varieties need to be verified at different agro-ecological zones. A study was therefore conducted to investigate the impacts of irrigation at different growth stages on yield and yield attributes of the three varieties of mustard. 


\section{MATERIALS AND METHODS}

\section{Study site}

The experiment was conducted at a farmer's field near Rahmatpur, Mymensingh, Bangladesh $\left(24^{\circ} 45^{\prime} \mathrm{N}\right.$ and $90^{\circ} 24^{\prime} \mathrm{E}$ ). The topography of the land is medium high and the soil belongs to the Old Brahmaputra Flood Plain. The major climatic parameters including air temperature, humidity, rainfall, wind speed, sun shine, solar radiation and evaporation data during the experimental period were collected from the weather yard of the Department of Irrigation and Water Management of Bangladesh Agricultural University. The soil type was silty clay. The soil up to $60 \mathrm{~cm}$ depth was somewhat homogenous in terms of the observed physicochemical properties of the soil (Table 1).

Table 1. Selected physicochemical properties of the soil at different depths of the experimental field

\begin{tabular}{|c|c|c|c|c|c|c|c|c|c|}
\hline \multirow{2}{*}{$\begin{array}{l}\text { Soil } \\
\text { depth } \\
(\mathrm{cm})\end{array}$} & \multicolumn{3}{|c|}{$\begin{array}{l}\text { Particle } \\
\text { distribution (\%) }\end{array}$} & \multirow[t]{2}{*}{$\begin{array}{l}\text { Textural } \\
\text { class }\end{array}$} & \multirow{2}{*}{$\begin{array}{l}\text { Bulk } \\
\text { density } \\
\left(\mathrm{g} \mathrm{cm}^{-3}\right)\end{array}$} & \multirow{2}{*}{$\begin{array}{l}\text { Porosity } \\
(\%)\end{array}$} & \multirow{2}{*}{$\begin{array}{l}\text { Field } \\
\text { capacity } \\
(\%)\end{array}$} & \multirow[t]{2}{*}{$\mathrm{pH}$} & \multirow{2}{*}{$\begin{array}{l}\text { EC } \\
\left(\mathrm{dS} \mathrm{cm}{ }^{-1}\right)\end{array}$} \\
\hline & Sand & Silt & Clay & & & & & & \\
\hline $0-15$ & \multirow{4}{*}{3} & \multirow{4}{*}{54} & \multirow{4}{*}{43} & \multirow{4}{*}{ silty clay } & 1.42 & 50.8 & 42.4 & 5.68 & 768 \\
\hline $15-30$ & & & & & 1.43 & 50.3 & 42.4 & 5.96 & 702 \\
\hline $30-45$ & & & & & 1.43 & 50.1 & 42.4 & 6.06 & 679 \\
\hline $45-60$ & & & & & 1.44 & 50.7 & 42.4 & 6.16 & 631 \\
\hline
\end{tabular}

\section{Experiment}

The soil of the experimental land was first opened with a power tiller and kept exposed to the sun. Later, it was prepared by several ploughing followed by laddering. The weeds and debris were removed from the land. After final land preparation, the plots were demarcated and levees were made around the individual plots to retain irrigation water. The buffer zones were made to prevent the effect of seepage of water between the adjacent plots. Doses of nitrogen, phosphorus, potassium, sulphur, zinc and boron fertilizer for mustard cultivation were $66.7,41.7,37.5,33.3,3.3$ and $3.3 \mathrm{~kg} \mathrm{ha}^{-1}$, respectively as recommended by BARC (FRG, 2012).

The experimental field was laid out in split-plot with four irrigation treatments in main plots and varieties in sub-plots and each treatment having three replications. The $6 \mathrm{~m} \times 4 \mathrm{~m}$ layout experimental units or plots were separated from each other by $70 \mathrm{~cm}$ wide buffer zone to prevent seepage between nearby plots. Similarly, the replication blocks were separated from each other by $30 \mathrm{~cm}$ wide buffer zone. Irrigation water was made available to the experimental plots by using hose pipe provided in the buffer zone between two replicate blocks.

Irrigation scheduling is defined as when to irrigate and how much water to irrigate. There are different approaches of irrigation scheduling on the basis of growth stage, permissible soil water depletion and measured pan evaporation. In this study, irrigation water was applied to the crop on the basis of growth stages. The four irrigation treatments were as follows: control $\left(\mathrm{T}_{1}\right)$, irrigation at the vegetative stage (25-30 days after sowing (DAS) up to field capacity $\left(\mathrm{T}_{2}\right)$, irrigation at the flowering stage (45-50 DAS) up to field capacity $\left(T_{3}\right)$, irrigation at the vegetative (25-30 DAS) and flowering stage (45-50 DAS) up to field capacity $\left(T_{4}\right)$. Three varieties of mustard selected for the study were as follows: Binasarisha-7 (Brassica juncea $\left.L\right)\left(V_{1}\right)$, Binasarisha-8 (Brassica juncea $L)\left(V_{2}\right)$ and Binasarisha-4 (Brassica napus $L$ ) $\left(V_{3}\right)$.

The mustard seeds were sown by line on 03 November, 2012. The seed rate was $7 \mathrm{~kg} \mathrm{ha}^{-1}$. After line sowing the seeds, laddering was done to cover the seeds with loose soils. A calendar of various operations done during the experiment and starting time of different growth stages were recorded (Table 2). Several weeds grew in the experimental plots that were uprooted manually. Weeding was done after 20 DAS. Irrigation water was applied as per schedule of the irrigation treatments. Two important growth stages of mustard were identified for irrigation as predefined by experimental treatments. Crop was harvested on 25 February, 2013 at the time of $70 \%$ maturity. Harvesting was done carefully to avoid field losses. 


\section{Data collection}

Ten sample plants were selected randomly from each treatment for further data collection. Different agronomic data including plant height, number of branch, number of pod/plant, pod length, number of seed/pod, straw weight, and 1000-seed weight were recorded.

Table 2. Calendar of different activities during the growing season and different growth stages

\begin{tabular}{lc}
\hline Different activities & Days after sowing \\
\hline Sowing & 0 \\
Germination & 12 \\
Thinning & 20 \\
Weeding & 28 \\
Staring of Vegetative stage & 28 \\
First irrigation & 30 \\
Flowering stage & 47 \\
Second irrigation & 50 \\
Starting of Fruit development stage & 67 \\
Staring of Ripening stage & 80 \\
Harvesting & 114 \\
\hline
\end{tabular}

Irrigation water needed was calculated at each stage of the crop growth. Soil moisture content in each plot was measured by gravimetric method (oven dried at $105^{\circ} \mathrm{C}$ for $24 \mathrm{~h}$ ) up to $0-60 \mathrm{~cm}$ depth for every $15 \mathrm{~cm}$ increment at the time of sowing, before and after irrigation, and at the time of harvest. Depth of irrigation water needed was calculated using the following equation:

Irrigation water depth, $\mathrm{d}=\sum_{1}^{4} \frac{\left(\theta_{c}-\theta\right)}{100} \times 15$

where $\theta_{c}=$ field capacity ( $\%$ volume) and $\theta=$ volumetric soil water content (\%). In this equation '15' indicates soil depth for every $15 \mathrm{~cm}$ increment for $0-60 \mathrm{~cm}$. The effective root zone depth of mustard was assumed $60 \mathrm{~cm}$. This depth was multiplied by the area of each plot to calculate the volume of water required.

\section{Data simulation}

HYDRUS-1D model (Šimunek et al., 2013) was used to see the soil water dynamics between the sampling events and estimate overall soil water storage in root zone area during the study period. Soil physical properties, weather parameters, and crop information collected during the experiment were used as input to this model. A deterministic approach, based on the numerical solution of the Richards equation by means of linear finite elements, was used to simulate soil water movement. The description of the simulation process is brief here because it was not the main focus of the study. This type of simulation study using HYDRUS model has been described in Amin et al. (2014).

\section{Water use efficiency}

Total accumulated crop water use or evapotranspiration (ET) was calculated from the water balance equation:

$$
E_{t}=I+R-D+\Delta S_{m}
$$

where $E_{t}=$ water use by the crop or evapotranspiration $(\mathrm{cm}), I=$ irrigation $(\mathrm{cm}), R=$ rainfall $(\mathrm{cm}), D=$ drainage $(\mathrm{cm})$, and $\Delta \mathrm{S}_{\mathrm{m}}=$ change in soil moisture in the experimental plots from beginning to the end of the growing season. 
Drainage was ignored in this experiment because the total rainfall during the experimental period was only $2.01 \mathrm{~cm}$, and the total amount was considered as effective rainfall. Water use efficiency was calculated as:

$$
\text { WUE }=\frac{Y}{E T}
$$

where WUE is the water use efficiency $\left(\mathrm{t} \mathrm{ha}^{-1} \mathrm{~cm}^{-1}\right)$, ET is evapotranspiration $(\mathrm{cm})$ and $\mathrm{Y}$ is the yield $(\mathrm{t})$. Water expense is the sum of the irrigation water and rainfall.

\section{Data analysis}

The analysis of variance (ANOVA) was done following the methods described by Gomez and Gomez (1984). MSTAT-C computer package (Russel and Eisensmith, 1983) was used to carry out the statistical analysis. The significance of difference among the means was compared by using the standard error. The standard error was computed by $s / \sqrt{n}$, where $s$ is the standard deviation and $n$ is the number of observation.

\section{RESULTS AND DISCUSSION}

\section{Effect of irrigation treatments}

Plant height was significantly influenced by the levels of irrigation (Table 3). The tallest plant height was found in the treatment of irrigation at the flowering stage $\left(T_{3}\right)$ and the smallest plant height in the treatment of no irrigation $\left(\mathrm{T}_{1}\right)$. Irrigation application at the flowering stage increased plant height significantly, so did by treatment $\mathrm{T}_{2}$ and $\mathrm{T}_{4}$. However, water supply at vegetative stage was comparatively less effective in increasing plant height in this study (Table 3) because the residual soil water content at vegetative stage was possibly still high enough to supply crop water uptake (Fig. 1). Figure 1 shows that the HYDRUS model simulated the effect of irrigation/rainfall and evapotranspiration on the root-zone-averaged water content adequately. The model simulated the increased soil water content in response to irrigation/rainfall events and the gradual declination of soil water content between two irrigation events due to the cumulative effect of evapotranspiration. The soil water content at different layers fluctuated considerably as shown by the measured data, but the root-zone-averaged water content as simulated by the model was sufficient for crop growth. Piri et al. (2011) observed that application of two irrigations significantly increased plant height. Two irrigations (vegetative and flowering stage) contributed to increased number of pods per plant. The number of pods/plant was significantly different among the four irrigation treatments (Table 3). The highest number of pod/plant (67.5) was obtained with $T_{4}$ and the lowest number of pods per plant (52.8) was in $T_{1}$. Begum and Paul (1993) conducted an experiment on the influence of soil moisture on growth, yield and water use efficiency of mustard. They also found that plant height at harvest and numbers of pods/plant were increased by irrigation. The maximum weight of 1000seed was $0.42 \mathrm{~g}$ for the treatment $\mathrm{T}_{3}$ and $\mathrm{T}_{4}$ and the lowest weight of 1000 -seed was $0.36 \mathrm{~g}$ for the treatment $\mathrm{T}_{1}$ (control) (Table 3). Begum and Paul (1993) concluded that 1000-seed weight was decreased by the lack of soil water availability for crop. The highest pod length was found in treatment $\mathrm{T}_{4}$ and the smallest pod length was obtained by the treatment $\mathrm{T}_{1}$ (Table 3 ). Irrigation at vegetative stage was helpful for increasing pod length, but two-irrigation treatment (vegetative and flowering stage) was more effective to increase pod length.

Table 3. Effect of irrigation treatments on yield attributes of mustard

\begin{tabular}{|c|c|c|c|c|c|c|c|c|}
\hline $\begin{array}{l}\text { Irrigation } \\
\text { treatment }\end{array}$ & $\begin{array}{l}\text { Plant } \\
\text { height }\end{array}$ & $\begin{array}{l}\text { Pod } \\
\text { length }\end{array}$ & $\begin{array}{l}\text { No. } \\
\text { of } \\
\text { pod/plant }\end{array}$ & $\begin{array}{l}\text { 1000-seed } \\
\text { weight }(\mathrm{g})\end{array}$ & $\begin{array}{l}\text { Seed } \\
\text { yield }\end{array}$ & Straw yield & $\begin{array}{l}\text { Biologic } \\
\text { al yield }\end{array}$ & $\begin{array}{l}\text { Harvest } \\
\text { index } \\
(\%)\end{array}$ \\
\hline $\mathrm{T}_{1}$ & $107.5 d^{1}$ & $3.17 c$ & $52.8 d$ & $0.36 c$ & $0.98 c$ & $2.99 c$ & $3.96 c$ & $24.65 a$ \\
\hline $\mathrm{T}_{2}$ & $113.4 c$ & $3.75 a$ & $63.8 b$ & $0.39 b$ & $1.10 c$ & $4.24 a b$ & $5.34 b$ & $20.23 b$ \\
\hline $\mathrm{T}_{3}$ & $131.3 a$ & $3.57 b$ & $57.8 c$ & $0.42 a$ & $1.21 b$ & $3.89 b$ & $5.10 \mathrm{~b}$ & $23.65 a$ \\
\hline $\mathrm{T}_{4}$ & $121.5 b$ & $3.81 a$ & $67.5 a$ & $0.42 a$ & $1.43 a$ & $4.46 a$ & $5.89 a$ & $24.30 \mathrm{a}$ \\
\hline LSD & 1.31 & 0.048 & 0.649 & 0.003 & 0.033 & 0.111 & 0.122 & 0.856 \\
\hline
\end{tabular}

${ }^{1}$ Means followed by the same letter within each column are not significantly different $(\mathrm{P}<0.01)$.

$\mathrm{T}_{1}$ : no irrigation; $\mathrm{T}_{2}$ : irrigation at vegetative stage; $\mathrm{T}_{3}$ : irrigation at flowering stage;

$\mathrm{T}_{4}$ : irrigation at vegetative and flowering stage. 

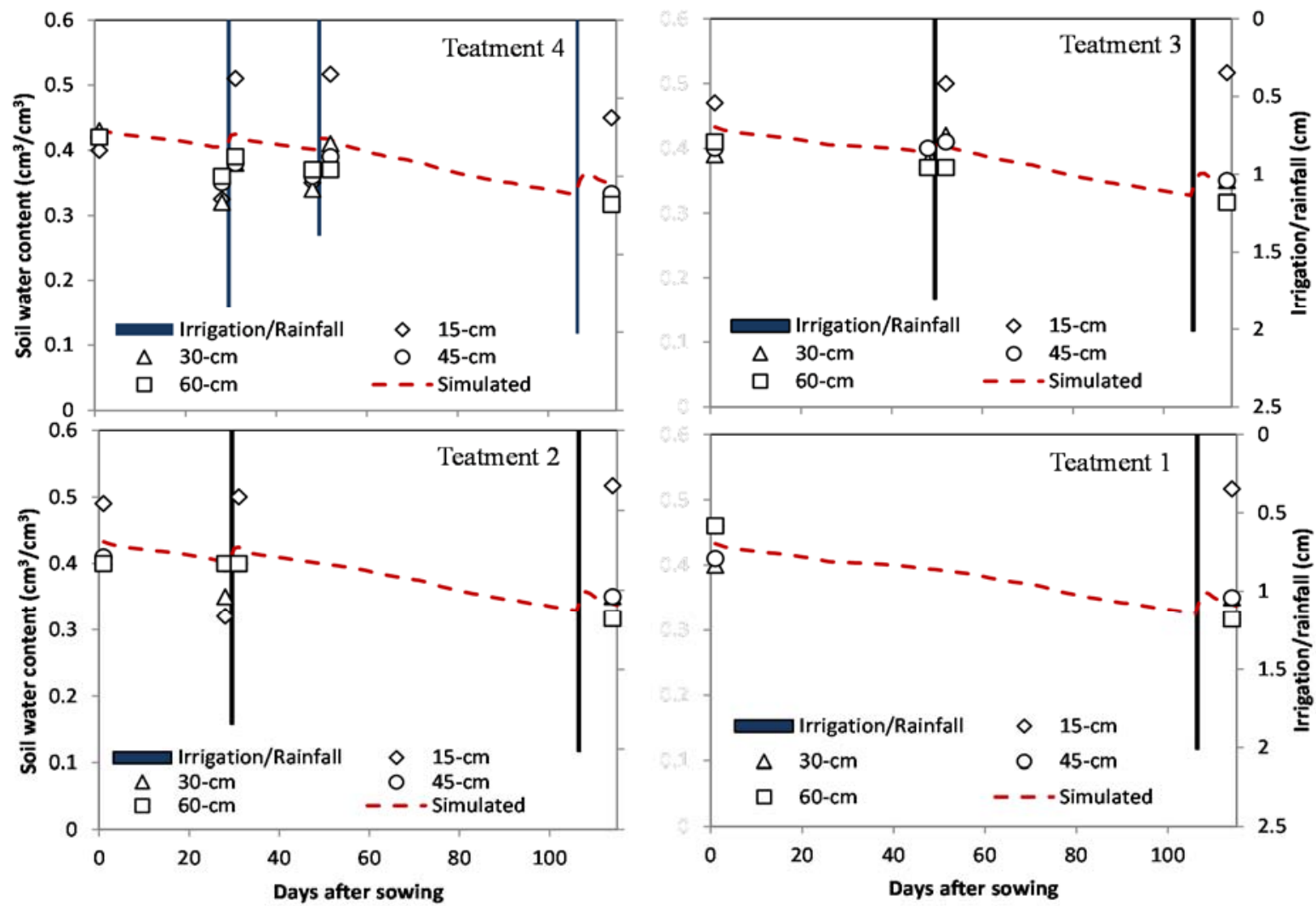

Figure 1. Soil water dynamics at different soil layers for different irrigation treatments $\left(T_{1}\right.$ : no irrigation; $T_{2}$ : irrigation at vegetative stage; $T_{3}$ : irrigation at flowering stage; $T_{4}$ : irrigation at vegetative and flowering stage). Dotted line shows model simulated root-zone-averaged volumetric soil water content. The column at the end depicts a rainfall event of $2.01 \mathrm{~cm}$ and other columns irrigation events.

Table 4. Effect of varieties on yield attributes of mustard

\begin{tabular}{|c|c|c|c|c|c|c|c|c|}
\hline $\begin{array}{l}\text { Irrigation } \\
\text { treatment }\end{array}$ & $\begin{array}{l}\text { Plant } \\
\text { height }\end{array}$ & $\begin{array}{l}\text { Pod } \\
\text { length }\end{array}$ & $\begin{array}{l}\text { No. of } \\
\text { pod/plant }\end{array}$ & $\begin{array}{l}\text { 1000-seed } \\
\text { weight }(\mathrm{g})\end{array}$ & $\begin{array}{l}\text { Seed } \\
\text { yield }\end{array}$ & $\begin{array}{l}\text { Straw } \\
\text { yield } \\
\left(\mathrm{t} \mathrm{ha}^{-1}\right)\end{array}$ & $\begin{array}{l}\text { Biological } \\
\text { yield }\end{array}$ & $\begin{array}{l}\text { Harvest } \\
\text { index }\end{array}$ \\
\hline $\mathrm{V}_{1}$ & $132.8 a^{1}$ & $2.87 c$ & $66.23 b$ & $0.39 b$ & $1.25 a$ & $3.74 b$ & $4.99 \mathrm{~b}$ & $25.43 a$ \\
\hline$V_{2}$ & $124.1 b$ & $3.02 b$ & $74.50 \mathrm{a}$ & $0.40 a$ & $1.23 a$ & $4.05 a$ & $5.29 a$ & 23.31b \\
\hline$V_{3}$ & $98.3 c$ & $4.84 a$ & $40.63 c$ & $0.40 a$ & $1.05 b$ & $3.89 a$ & $4.95 b$ & $20.87 c$ \\
\hline LSD & 0.98 & 0.036 & 0.486 & 0.002 & 0.025 & 0.084 & 0.091 & 0.642 \\
\hline
\end{tabular}

${ }^{1}$ Means followed by the same letter within each column are not significantly different $(P<0.01)$.

$\mathrm{V}_{1}$ : Binasarisha-7; $\mathrm{V}_{2}$ : Binasarisha-8; $\mathrm{V}_{3}$ : Binasarisha-4. 
Table 5. Interaction effects of irrigation treatments and varieties on yield

\begin{tabular}{|c|c|c|c|}
\hline Interaction & $\begin{array}{l}\text { Seed yield } \\
\left(\mathrm{t} \mathrm{ha}^{-1}\right)\end{array}$ & $\begin{array}{l}\text { Straw yield } \\
\left.(\mathrm{t} \mathrm{ha})^{-1}\right)\end{array}$ & $\begin{array}{l}\text { Harvest } \\
\text { Index (\%) }\end{array}$ \\
\hline$\overline{V_{1} T_{1}}$ & $1.29 a$ & $2.65 \mathrm{e}$ & $41.1 \mathrm{a}$ \\
\hline$V_{1} T_{2}$ & $1.34 a$ & $4.33 a b c$ & $29.4 \mathrm{bcd}$ \\
\hline$V_{1} T_{3}$ & $0.94 b$ & $3.79 \mathrm{~cd}$ & 24.8de \\
\hline $\mathrm{V}_{1} \mathrm{~T}_{4}$ & $1.43 a$ & $4.18 b c$ & $31.9 b c$ \\
\hline $\mathrm{V}_{2} \mathrm{~T}_{1}$ & $1.03 b$ & $3.24 \mathrm{de}$ & $29.9 \mathrm{bcd}$ \\
\hline$V_{2} T_{2}$ & $1.25 a$ & 4.71ab & 26.1cde \\
\hline$V_{2} T_{3}$ & $1.25 a$ & $4.04 b c$ & $29.5 \mathrm{bcd}$ \\
\hline$V_{2} T_{4}$ & $1.4 a$ & $4.23 a b c$ & $31.0 \mathrm{bcd}$ \\
\hline$V_{3} T_{1}$ & $0.62 c$ & $3.06 \mathrm{de}$ & $21.4 \mathrm{e}$ \\
\hline$V_{3} T_{2}$ & $0.56 c$ & $3.69 \mathrm{~cd}$ & $20.4 e$ \\
\hline$V_{3} T_{3}$ & $1.44 a$ & $3.84 \mathrm{~cd}$ & $34.4 b$ \\
\hline $\mathrm{V}_{3} \mathrm{~T}_{4}$ & $1.45 a$ & $4.99 a$ & $28.2 \mathrm{bcd}$ \\
\hline LSD & 0.099 & 0.33 & 2.57 \\
\hline $\begin{array}{ll}\text { Level } & \text { of } \\
\text { significant } & \end{array}$ & $P<0.01$ & $P<0.05$ & $P<0.01$ \\
\hline
\end{tabular}

${ }^{1}$ Means followed by the same letter within each column are not significantly different.

$T_{1}$ : no irrigation; $T_{2}$ : irrigation at vegetative stage; $T_{3}$ : irrigation at flowering stage;

$\mathrm{T}_{4}$ : irrigation at vegetative and flowering stage; $\mathrm{V}_{1}$ : Binasarisha-7; $\mathrm{V}_{2}$ : Binasarisha-8; $\mathrm{V}_{3}$ : Binasarisha-4.

Table 6. Water expense, water use and water use efficiency for mustard production under different irrigation treatments

\begin{tabular}{|c|c|c|c|}
\hline $\begin{array}{l}\text { Irrigation } \\
\text { Treatments }\end{array}$ & $\begin{array}{l}\text { Water expense } \\
(\mathrm{cm})\end{array}$ & $\begin{array}{l}\text { Water use } \\
\text { (cm) }\end{array}$ & $\begin{array}{l}\text { Water use } \\
\text { efficiency } \\
\left(\mathrm{t} \mathrm{ha} \mathbf{~}^{-1} \mathrm{~cm}^{-1}\right)\end{array}$ \\
\hline$\overline{T_{1}}$ & 2.01 & 2.05 & 0.48 \\
\hline $\mathrm{T}_{2}$ & 3.85 & 3.56 & 0.31 \\
\hline $\mathrm{T}_{3}$ & 3.14 & 2.68 & 0.45 \\
\hline $\mathrm{T}_{4}$ & 5.24 & 5.13 & 0.28 \\
\hline
\end{tabular}

$T_{1}$ : no irrigation; $T_{2}$ : irrigation at vegetative stage; $T_{3}$ : irrigation at flowering stage;

$\mathrm{T}_{4}$ : irrigation at vegetative and flowering stage.

Two-irrigation treatment $\mathrm{T}_{4}$ produced the highest seed yield of $1.43 \mathrm{t} \mathrm{ha}^{-1}$ and $\mathrm{T}_{1}$ produced the lowest seed yield of $0.98 \mathrm{t} \mathrm{ha}^{-1}$ (Table 3 ). The seed yield under $\mathrm{T}_{4}$ increased significantly $(\mathrm{P}<0.01)$ over that under $T_{1}, T_{2}$ and $T_{3}$. The seed yield under $T_{3}$ (irrigation at flowering stage) was $1.21 \mathrm{t} \mathrm{ha}{ }^{-1}$, which was greater than the seed yield under irrigation at vegetative stage $\left(T_{2}\right)$ and no irrigation $\left(T_{1}\right)$. These results indicate that two irrigations fulfilled the water demand of mustard crop satisfactorily, whereas crop presumably suffered mild water stress condition particularly in partial root zone area when irrigation was applied only once (Fig. 1). Mila et al. (2013) pointed out the necessity of irrigation at the vegetative and flowering stages of mustard under similar climatic condition. Mandal et al. (2006) also obtained higher yield of mustard with two-irrigation compared to one-irrigation with same amount of water. The straw yield under the irrigation treatments ranged from 2.99 to $4.46 \mathrm{t} \mathrm{ha}^{-1}$ (Table 3 ). Treatment $\mathrm{T}_{4}$ again produced the highest straw yield $\left(4.46 \mathrm{t} \mathrm{ha}^{-1}\right)$ and $\mathrm{T}_{1}$ produced the lowest yield $\left(2.99 \mathrm{t} \mathrm{ha}^{-1}\right)$, suggesting that straw yield of mustard decreased due to the water stress condition in control treatment. Piri et al. (2011) also reported that application of two irrigations significantly increased plant height and number of primary branches per plant of mustard compared to single irrigation, which resulted in significantly higher straw yield. The treatment $\mathrm{T}_{4}$ produced the highest biological yield of $5.89 \mathrm{t} \mathrm{ha}^{-1}$ and $\mathrm{T}_{1}$ produced the lowest yield of $3.96 \mathrm{t} \mathrm{ha}^{-1}$. Irrigation water supplied both vegetative and flowering stage increased the seed yield as well as the biological yield of mustard. Harvest index did not differ 
significantly for the treatments $T_{1}, T_{3}$ and $T_{4}$ (Table 3). In contrast, Begum and Paul (1993) found that harvest index was influenced by irrigation. The effectiveness of irrigation may vary with the soil types, residual soil water content and weather.

\section{Effect of varieties}

The varietal effect on plant height was significant at $1 \%$ level of probability (Table 4$)$. Binasarisha-7 $\left(\mathrm{V}_{1}\right)$ produced taller plant than Binasarisha-8 $\left(\mathrm{V}_{2}\right)$ and Binasarisha-4 $\left(\mathrm{V}_{3}\right)$. The highest number of pods per plant (74.50) was obtained from $V_{2}$ and the lowest number of pods per plant (40.63) was produced by $V_{3}($ Table 4 ). There was a significant difference between the highest and the lowest values. Binasarisha- 4 and Binasarisha-8 produced $0.40 \mathrm{~g}$ and Binasarisha-7 produced $0.39 \mathrm{~g}$ of 1000-seed weight (Table 4), but the difference was not significant. There was significant effect of varieties on pod length. The longest pod was found in variety $V_{3}$ and the shortest pod in $\mathrm{V}_{2}$ (Table 4).

Binasarisha-7 $\left(\mathrm{V}_{1}\right)$ produced the highest seed yield of $1.25 \mathrm{t} \mathrm{ha}^{-1}$ and Binasarisha- $4\left(\mathrm{~V}_{3}\right)$ gave the lowest seed yield of $1.05 \mathrm{t} \mathrm{ha}^{-1}$ (Table 4). The seed yield of $\mathrm{V}_{1}$ was significantly higher than that of $\mathrm{V}_{3}(\mathrm{P}<0.01)$. The seed yield of variety $V_{1}$ and $V_{2}$ was statistically same. The straw yield ranged from 3.74 to $4.05 \mathrm{t} \mathrm{ha}^{-1}$ for different varieties (Table 4). The highest straw yield $\left(4.05 \mathrm{t} \mathrm{ha}^{-1}\right)$ was for variety $V_{2}$ and the lowest yield $(2.99 \mathrm{t}$ $\mathrm{ha}^{-1}$ ) for $\mathrm{V}_{1}$. The variety $\mathrm{V}_{2}$ therefore made the highest biological yield of $5.29 \mathrm{tha}^{-1}$ and $V_{3}$ gave the lowest biological yield of $4.95 \mathrm{t} \mathrm{ha}^{-1}$. The effect of variety on harvest index was also significant. Maximum harvest index $(25.43 \%$ ) was obtained for Binasarisha-7 whereas $20.87 \%$ harvest index for Binasarisha-4 was the lowest (Table 4). Pradhan et al. (2014) obtained significantly different yield of three mustard varieties.

\section{Interaction effects of irrigation treatments and varieties}

The interaction effect of irrigation treatments and varieties on the seed yield of mustard was significant (Table 5). The two-irrigation treatment $\left(\mathrm{T}_{4}\right)$ produced higher seed yield for all varieties studied. The highest seed yield was $1.45 \mathrm{t} \mathrm{ha}^{-1}$ for the combination of two-irrigation treatment ( $\left.\mathrm{T}_{4}\right)$ and Binasarisha-4. The lowest seed yield was $0.56 \mathrm{t} \mathrm{ha}^{-1}$ under irrigation at the vegetative stage $\left(\mathrm{T}_{2}\right)$ for Binasarisha-4. It appears that for producing seed yield Binasarisha- 4 was the most responsive to the irrigation treatments $\left(T_{2}-T_{4}\right)$. In contrast, the yield differences among the stage-wise irrigation treatments $\left(T_{2}-T_{4}\right)$ were not statistically significant for Binasarisha-8 (Table 5). Single irrigation was found effective for increasing straw yield for Binasarisha-7 and Binasarisha-8 but not for Binasarisha-4 (Table 5). The highest biological yield was $6.44 \mathrm{t} \mathrm{ha}^{-1}$ for the combination of two-irrigation treatment and Binasarisha-4. The highest harvest index was $41.05 \%$ under control treatment (no irrigation) for Binasarisha-7.

\section{Water use efficiency}

The highest water expense $(5.24 \mathrm{~cm})$ was in treatment $T_{4}$ because there were two irrigations at two growth stages (Table 6 and Fig. 1). Total effective rainfall was $2.01 \mathrm{~cm}$ during the crop period. Water use was calculated by summing up the effective rainfall, irrigation and profile soil moisture depletion. The highest water use efficiency $\left(0.48 \mathrm{t} \mathrm{ha}^{-1} \mathrm{~cm}^{-1}\right)$ was observed in $T_{1}$, obviously because of no irrigation. The water use efficiency decreased with the increase of irrigation and it was lowest $\left(0.28 \mathrm{tha}^{-1} \mathrm{~cm}^{-1}\right)$ in treatment $T_{4}$ followed by treatment $T_{2}\left(0.31 \mathrm{t} \mathrm{ha}^{-1} \mathrm{~cm}^{-1}\right)$. Mila et al. (2013) reported that for application of two irrigations the yield of mustard increased, but the water use efficiency decreased.

\section{CONCLUSIONS}

Most of the yield attributes of mustard were significantly influenced by the irrigation treatments and varieties. The highest seed yield of mustard was obtained under the combination of irrigation at vegetative and flowering stage and Binasarisha-4, and the lowest seed yield was obtained when irrigation was not applied for the same variety. On an average for all the irrigation treatments Binasarisha-7 produced the highest yield. Two-irrigation treatment (irrigation at vegetative and flowering stage) gave the highest yield. Although the soil water content at different layers fluctuated considerably, the root-zone-averaged water content as simulated by the model was sufficient for crop growth. The highest water use efficiency for seed production was obtained under no-irrigation and the lowest water use efficiency was in two-irrigation treatment. 


\section{REFERENCES}

1. Acharjee TK, 2013. Effect of sugar mill's waste water on growth and yield of Mustard, MS Thesis, Department of Irrigation and Water Management, Bangladesh Agricultural University, Mymensingh, Bangladesh.

2. Amin MGM, J Šimunek, and M Lægdsmand, 2014. Simulation of the redistribution and fate of contaminants from soil-injected animal manure. Agricultural Water Management, 131: 17-29.

3. Amin MGM, MH Ali, and AKMR Islam, 2004. Agro-climatic analysis for crop planning in Bangladesh. Bangladesh Journal of Agricultural Engineering, 15: 31-40.

4. BBS (Bangladesh Bureau of Statistics), 2011. Yearbook of Agricultural Statistics of Bangladesh, Statistics and Information Division, Ministry of planning, Government of the People's Republic of Bangladesh, Dhaka, Bangladesh.

5. Begum FA and NK Paul, 1993. Influence of soil moisture on growth, water use and yield of mustard. Journal of Agronomy and Crop Science, 170: 136-141.

6. Bharadwaj DR, DP Bharadwaj, S Chauhan, and RKS Chauhan, 2014. Yield Variation in Mustard Crop Due To Sewage Irrigation. AISECT University Journal, 3: 1-4.

7. CA (Comprehensive Assessment of Water Management in Agriculture), 2007. Water for Food, Water for Life: A Comprehensive Assessment of Water Management in Agriculture. Earthscan, London, UK, and International Water Management Institute, Colombo, Sri Lanka.

8. Chauhan CPS and RB Singh, 2004. Mustard performs well even with saline irrigation. Indian Farming, 42: 17-20.

9. FRG, 2012. Fertilizer Recommendation Guide, Bangladesh Agricultural Research Council (BARC), Farmgate, Dhaka 1215.

10. Gomez KA and AA Gomez, 1984. Statistical Procedures Agricultural Research, Wiley, New York, USA.

11. Hussain I, L Raschid, MA Hanjra, F Marikar, and W van der Hoek, 2002. Wastewater use in agriculture: Review of impacts and methodological issues in valuing impacts. Working Paper 37, International Water Management Institute, Colombo, Sri Lanka.

12. Kahlown MA, M Akram, ZA Soomro, and W Kemper, 2009. Prospectus of growing barley and mustard with saline groundwater irrigation in fine and coarse-textured soils of Cholistan desert. Irrigation and Drainage, 58: 469-481.

13. Mandal KG, KM Hati, AK Misra, and KK Bandyopadhyay, 2006. Assessment of irrigation and nutrient effects on growth, yield and water use efficiency of Indian mustard (Brassica juncea) in central India. Agricultural Water Management, 85: 279-286.

14. Miah MAM and QM Alam, 2009. Adoption and Relative Profitability of Mustard Production in Bangladesh. In Annual Report 2007, Oilseed Research Centre, Bangladesh Agricultural Research Institute, Joydevpur, Gazipur-1701, Bangladesh.

15. Mila AJ, AA Sarkar, NN Karim, and MN Islam, 2013. Yield response of a mustard mutant variety to different times of irrigation. Bangladesh Journal of Scientific Research, 26: 89-93.

16. Panda BB, SK Bandyopadhyay, and YS Shivay, 2004. Effect of irrigation level, sowing dates and varieties on yield attributes, yield, consumptive water use and water-use efficiency of Indian mustard. Indian Journal of Agricultural Sciences, 74: 339-342.

17. Pandey N, RS Tripathi, and BN Mittra, 2004. N, P and water management in green gram-ricemustard cropping system. Annals of Agricultural Research, 25: 298-302.

18. Piri I, MM Nik, A Tavassoli, and F Rastegaripour, 2011. Effect of irrigation intervals and sulphur fertilizer on growth analyses and yield of Brassica juncea. African Journal of Microbiology Research, 5: 3640-3646.

19. Pradhan S, VK Sehgal, DK Das, AK Jain, KK Bandyopadhyay, R Singh, and PK Sharma, 2014. Effect of weather on seed yield and radiation and water use efficiency of mustard cultivars in a semiarid environment. Agricultural Water Management, 139:43-52. 
20. Russel DF and SP Eisensmith, 1983. MSTAT-C. Crop Soil Science Department, Michigan State University, USA.

21. Shekhawat K, SS Rathore, OP Premi, BK Kandpal, and JS Chauhan, 2012. Advances in Agronomic Management of Indian Mustard (Brassica juncea (L.) Czernj. Cosson): An Overview. International Journal of Agronomy, 2012:14.

22. Šimunek J, M Šejna, H Saito, M Sakai, and MTh van Genuchten, 2013. The HYDRUS-1D software package for simulating the one-dimensional movement of water, heat, and multiple solutes in variably-saturated media. Version 4.16. Department of Environmental Sciences, University of California, Riverside, California, USA.

23. Singh A and SN Panda, 2012. Effect of saline irrigation water on mustard (brassica juncea) crop yield and soil salinity in a semi-arid area of north India. Experimental Agriculture, 48(1):99-110.

24. UN Water(http://www.unwater.org/statistics/statistics-detail/en/c/211807/), 2014. 